\title{
Fertility measures in Polish Black-and-White cattle. 1. Genetic parameters of heifer fertility traits*
}

\author{
W. Jagusiak \\ Agricultural University of Cracow, Department of Genetics and Animal Breeding \\ Mickiewicza 24/28, 30-059 Kraków, Poland
}

(Received 14 July 2004; revised version 13 May 2005; accepted 4 August 2005)

\begin{abstract}
Genetic parameters of heifer fertility measures were estimated. Data were records of 42283 first-parity Black-and-White cows. The percentage of cows that did not repeat heat was 73 at the $56^{\text {th }}$ day and 69 at the $72^{\text {nd }}$ day after first insemination. Heritabilities of non-return rates to the $56^{\text {th }}$ day and $72^{\text {nd }}$ day were 0.012 and 0.010 , respectively. Heritabilities of age at first insemination, age at conception and age at calving were $0.324,0.312$ and 0.296 , respectively. Phenotypic correlations ranged from 0.78 between age at first service and age at conception to 0.98 between age at conception and age at calving. The genetic correlations were high ( 0.96 and higher). Genetic correlations between non-return rates and the remaining traits ranged from -0.11 to 0.10 .
\end{abstract}

KEY WORDS: dairy cattle, fertility, genetic parameters, linear animal model

\section{INTRODUCTION}

Improvement of milk production traits has been a main breeding goal in the Polish Black-and-White cattle population. During the last 20 years, holsteinistion and selection have led to an increase of milk yield but have caused unfavourable trends in reproductive performance. Fertility traits are considered very important because of their impact on the economics of dairy cattle breeding. The following consequences of low fertility were listed by Hodel et al. (1995): higher insemination costs, decrease of milk and meat production (fewer progeny born), increase in

\footnotetext{
"Supported by the State Committee for Scientific Research, Grant No. 2 P06D 03827

Corresponding author: e-mail: rzjagusi@cyf-kr.edu.pl
} 
culling rate, and less intensive selection. About $20-30 \%$ of all culling has been due to fertility problems (Boichard and Manfredi, 1992; Hoekstra et al., 1994). Measures of fertility are defined as intervals (calving intervals, days open, days to first service, service period); others illustrate the efficiency of insemination (e.g., conception rate, non-return rate, average number of services per conception) (Pryce et al., 1998). Cow fertility is affected by breed (Oltenacu et al., 1991; Antkowiak and Pytlewski, 1997), percentage of HF genes (Ziemiński et al., 1991; Hoekstra, 1994), age of cow (Kamieniecki et al., 1991) and year of calving (Brzozowski, 1985; Jansen; 1985; Bagnato and Oltenacu, 1994). Other factors such as feeding, health, oestrus detection, or determination of time of insemination, may be directly influenced by the breeder (Kuczaj, 1985; Boichard and Manfredi, 1992).

In practice, the main factor decreasing the fertility of dairy cows is increase of milk production traits, which is negatively correlated with fertility (Hansen et al., 1983; Nebel and McGiliard; 1993, Hoekstra et al., 1994; Pryce et al., 1998; Lucy, 2001; Veerkamp et al., 2001). High-producing cows have 12 days more from calving to the next conception and a significantly lower first service conception rate. Better herd management in high-producing herds can partly reduce the negative effect of high production on fertility (Bagnato and Oltenacu, 1994). Lawson et al. (2004) found moderate relationships between milk production efficiency and several reproductive disorders in the Danish dairy cattle population. A significant and unfavourable trend in fertility traits was observed in southeastern regions of the United States. The average interval from calving to conception increased from 120-130 days in 1976 to 160-180 days in 1999 (Washburn et al., 2002). In the same period the number of services per conception increased from 1.9-2.1 to 2.93.1. Average conception decreased from 52-53 to 33-35\%. The genetic trend for female fertility in Israeli Holstein dairy cattle population was close to zero, and the annual environmental trend was $0.2 \%$ (Weller and Ezra, 2003). Simultaneous selection for milk production and fertility traits is necessary because of negative correlation between yield traits and fertility (Strandberg and Danell, 1989; Oltenacu et al., 1991; Roxström et al., 2001).

Many authors have found an unfavourable relation between the percentage of Holstein-Friesian genes and the reproductive performance of cows (Ziemiński et al., 1991; Hoekstra et al., 1994). This finding was not confirmed by Royal et al. (2002) in Great Britain.

Recently, many countries participating in international bull breeding value evaluation have made significant improvements in cattle fertility. It is assumed that the genetic variability of some fertility traits is large enough to include them in the breeding goal. In many countries the fertility traits of dairy cattle have been routinely evaluated (Boichard et al., 1997; Cermák et al., 1997; Hyppänen and Juga, 1997; de Jong, 1997; Miglior et al., 1997; Pasman and Reihardt, 1997; 
Ranberg et al., 1997). The estimated breeding values of sires based on daughters' fertility are included in the total merit index in Germany (Miesenberger et al.; 1997, Thaller, 1997). In Denmark, five fertility traits are evaluated and combined in one index which is included in the total merit index. Two fertility traits are included in the total merit index in Finland (Hyppänen and Juga, 1997) and the Netherlands (de Jong, 1997). Fertility is also routinely evaluated in Germany (Pasman and Reihardt, 1997), France (Boichard et al., 1997), Italy (Miglior et al., 1997), Norway (Ranberg et al., 1997) and the Czech Republic (Cermák et al., 1997).

In Poland the fertility traits of dairy cattle have not been evaluated recently. Genetic parameters estimated for large populations using a relationship matrix as well as correlations between fertility and other economically important traits are also not available.

The purpose of this paper was to estimate the heritabilities of several fertility traits and the genetic and phenotypic correlations between them.

\section{MATERIAL AND METHODS}

Data were 763,073 records of Polish Black-and-White cows born between 1996 and 2000. Each record consisted of the cow registration number, pedigree (parents and grandparents), date of birth, date of first insemination, date of conception and date of calving. Mean inbreeding for Polish Black-and-White cows born between 1996 and 1999 was less then $0.5 \%$ and could be ignored (Jagusiak and Ptak, 2003). After formal edits, records of the cows with incomplete data were removed and a file with 289,500 records of cows were created. The cows were daughters of 3927 sires. The records of daughters of sires with less than 20 progeny were deleted and from the total of 2018 sires with 20 or more daughter records, 1018 bulls were randomly chosen. A random number generator was used to draw the bulls. Probability for drawing each single bull was set to 0.5 . Cows assigned to herd-year-season subclasses with less than 10 contemporaries were removed from the file with daughters of the chosen bulls.

The final data set contained 42,283 records of cows that were daughters of 1018 sires. The cows calved for the first time in 785 herds and were allocated in 2217 herd-year-season and 1657 herd-year subclasses.

Most cows were born in 1998 and 1999 (Table 1). The average age of first service was highest for the oldest cows (582.2 days), and decreased to 511.9 days for the youngest cows born in 2000. The standard deviation for the youngest cows was the lowest (66 days); for the remaining groups it was higher but did not exceed 76 days. Age at conception showed a similar pattern: cows born in 1996 conceived on average 70 days later than cows born in 2000 . 
TABLE 1

Means and standard deviations for age at first service, age at conception, age at calving, NR56 and NR72 by birth year

\begin{tabular}{crcccccccccc}
\hline \multirow{2}{*}{$\begin{array}{c}\text { Year of } \\
\text { birth }\end{array}$} & $\mathrm{n}$ & \multicolumn{2}{c}{$\begin{array}{c}\text { Age at first } \\
\text { service }\end{array}$} & \multicolumn{2}{c}{$\begin{array}{c}\text { Age at } \\
\text { conception }\end{array}$} & \multicolumn{2}{c}{$\begin{array}{c}\text { Age at } \\
\text { calving }\end{array}$} & \multicolumn{2}{c}{ NR56 } & \multicolumn{2}{c}{ NR72 } \\
\cline { 3 - 14 } & & $\overline{\mathrm{x}}$ & SD & $\overline{\mathrm{x}}$ & SD & $\overline{\mathrm{x}}$ & SD & $\overline{\mathrm{x}}$ & SD & $\overline{\mathrm{x}}$ & SD \\
\hline 1996 & 2943 & 582.2 & 75.8 & 597.3 & 76.9 & 887.1 & 81.2 & 0.72 & 0.40 & 0.68 & 0.44 \\
1997 & 8535 & 550.9 & 74.9 & 568.6 & 78.4 & 846.6 & 83.2 & 0.73 & 0.39 & 0.67 & 0.43 \\
1998 & 10407 & 538.5 & 75.6 & 559.6 & 79.1 & 835.9 & 84.2 & 0.72 & 0.39 & 0.69 & 0.42 \\
1999 & 11869 & 534.7 & 73.1 & 555.2 & 77.9 & 836.4 & 82.5 & 0.74 & 0.39 & 0.69 & 0.42 \\
2000 & 8529 & 511.9 & 66.0 & 529.7 & 71.5 & 806.5 & 74.0 & 0.73 & 0.39 & 0.69 & 0.42 \\
\multirow{2}{*}{ Total } & 42283 & 537.6 & 75.5 & 556.8 & 79.0 & 835.8 & 83.2 & 0.73 & 0.39 & 0.69 & 0.42 \\
\hline
\end{tabular}

The differences between age at conception and age at first service (service period), which will be analysed in the next paper, were higher for cows born in 1998 and 1999 than for cows born in 1996. Age at first calving is highly correlated with age at conception and depends on days of pregnancy. Average ages at calving decreased for cows born in consecutive years, and ranged from 887.1 days for the oldest down to 806 for the youngest cows.

The group of pure Black-and-White cows was quite small (2.5\% of all cows) (Table 2). Most cows were assigned to groups with small (0.1-25\%) and average (25.1-50\%) contribution of Holstein-Friesian (HF) genes; 3122 (7.4\%) cows had more than $50 \%$ HF genes. Black-and-White cows and cows with a small

TABLE 2

Means and standard deviations for age at first service, age at conception and age at calving, by percentage of HF genes

\begin{tabular}{|c|c|c|c|c|c|c|c|c|c|c|c|}
\hline \multirow{2}{*}{$\begin{array}{l}\text { Percent- } \\
\text { age of } \\
\text { HF genes }\end{array}$} & \multirow[t]{2}{*}{$\mathrm{n}$} & \multicolumn{2}{|c|}{$\begin{array}{l}\text { Age at first } \\
\text { service }\end{array}$} & \multicolumn{2}{|c|}{$\begin{array}{l}\text { Age at } \\
\text { conception }\end{array}$} & \multicolumn{2}{|c|}{$\begin{array}{l}\text { Age at } \\
\text { calving }\end{array}$} & \multicolumn{2}{|c|}{ NR56 } & \multicolumn{2}{|c|}{ NR72 } \\
\hline & & $\overline{\mathrm{x}}$ & SD & $\overline{\mathrm{x}}$ & $\mathrm{SD}$ & $\overline{\mathrm{x}}$ & SD & $\overline{\mathrm{x}}$ & SD & $\overline{\mathrm{x}}$ & SD \\
\hline 0 & 1058 & 535.5 & 69.3 & 551.9 & 72.7 & 830.3 & 74.9 & 0.73 & 0.39 & 0.68 & 0.42 \\
\hline $0.1-25$ & 25625 & 533.6 & 72.2 & 552.7 & 76.5 & 831.5 & 80.2 & 0.73 & 0.39 & 0.69 & 0.42 \\
\hline $25.1-50$ & 12478 & 545.8 & 81.4 & 565.1 & 83.5 & 844.7 & 88.4 & 0.73 & 0.39 & 0.68 & 0.42 \\
\hline $50.1-75$ & 1732 & 544.3 & 82.2 & 564.3 & 82.8 & 843.8 & 88.3 & 0.73 & 0.40 & 0.69 & 0.43 \\
\hline $75.1-100$ & 1390 & 530.4 & 70.0 & 551.2 & 77.8 & 829.7 & 81.4 & 0.73 & 0.39 & 0,70 & 0.42 \\
\hline Total & 42283 & 537.6 & 75.5 & 556.8 & 79.0 & 835.8 & 83.2 & 0.73 & 0.39 & 0.69 & 0.42 \\
\hline
\end{tabular}

contribution of HF genes were younger than cows with $25.1-75 \%$ HF genes when first-time inseminated. Average age at first service was the lowest for the group of pure Holstein-Friesians (530.4 days).The following fertility measures were 
calculated for each cow: non-return rate to $56^{\text {th }}$ day (NR56), non-return rate to $72^{\text {nd }}$ day (NR72), age at first service, age at first conception, and age at first calving. Non-return rates were defined as binary traits based on whether or not the cow had a second insemination within 56 (or 72) days after first insemination. Neither NR56 and NR72 changed in consecutive birth years (Table 1), and they did not depend on the percentage of HF genes (Table 2).

(Co)variance components of the fertility traits were estimated by restricted maximum likelihood (REML) (Misztal and Perez-Enciso, 1993) with a relationship matrix, based on the following linear model:

$$
\mathbf{y}=\mathbf{X b}+\mathbf{Z Q g}+\mathbf{Z u}+\mathbf{e}
$$

where $\mathbf{y}$ is the vector of observations, $\mathbf{g}$ is the vector of fixed effects of genetic groups, $\mathbf{b}$ is the vector of fixed effects of herd-year of calving and month of calving, $\mathbf{u}$ is the vector of additive animal genetic effects, $\mathbf{e}$ is the vector of residual error, and $\mathbf{X}, \mathbf{Z}$ and $\mathbf{Q}$ are coincidence matrices. Matrix $\mathbf{G}=\mathbf{A}^{-1} \otimes \mathbf{G}_{0}$, where $\mathbf{A}^{-1}$ is a numerator relationship matrix and $\mathbf{G}_{0}$ a genetic (co)variance matrix between traits.

It is assumed that, $\mathrm{E}(\mathbf{u})=\mathbf{0}, \mathrm{E}(\mathbf{e})=\mathbf{0}, \mathrm{V}(\mathbf{u})=\mathbf{G}, \mathrm{V}(\mathbf{e})=\mathbf{R}, \operatorname{Cov}(\mathbf{u}, \mathbf{e})=\mathbf{0}$, and $\mathrm{E}(\mathbf{y})=\mathbf{X b}, \mathrm{V}(\mathbf{y})=\mathbf{Z G Z}+\mathbf{R}$. Matrix $\mathbf{R}=\mathbf{I} \otimes \mathbf{R}_{0}$, where $\mathbf{R}_{\mathbf{0}}$ is a residual (co)variance matrix between traits and $\otimes$ is the Kronecker product.

Genetic groups were created according to the rules given by Westell et al. (1988). Animals with unknown parents were assigned to genetic groups by birth year and percentage of Holstein-Friesian genes. Five groups for male and eight for female unknown parents were formed.

Variance components for NR56, NR72, age at first service, age at conception and age at calving were estimated using the single trait animal model. Estimated variances were used as prior values to estimate genetic and residual covariances between studied traits, using the multitrait animal model. Genetic and phenotypic correlations were computed based on estimated (co)variances.

\section{RESULTS}

The non-return rates at the $56^{\text {th }}$ or $72^{\text {nd }}$ days after insemination are very important traits used in selection indexes in some European countries (Thaller, 1997). These traits indicate the cow's ability to maintain a pregnancy over the period of early gestation. Interbull recommends using these traits in national evaluation systems. Gianola and Foulley (1983) suggested estimating genetic parameters for traits scored to two or several categories using a threshold model. Hansen et al. (2003) estimated genetic parameters for stillbirth using both threshold 
and linear approaches and found heritabilities estimated by the threshold model on average twice those obtained by the linear model. Increased computing time is a main disadvantage of threshold approach. The linear model was used for all traits analyzed in this paper.

The percentage of cows that did not repeat heat was $73 \%$ at the $56^{\text {th }}$ day and $69 \%$ at the $72^{\text {nd }}$ day after first insemination. Heritabilities for non-return rates were very low: 0.012 for NR56 and 0.01 for NR72. The highest heritability was found for age at first service (0.324). Heritabilities for age of conception and age at calving were slightly smaller and amounted to 0.312 and 0.296 , respectively (Table 3).

TABLE 3

Means and standard deviations of first-parity fertility traits $(n=42,283)$

\begin{tabular}{lcccc}
\hline Trait & $\overline{\mathrm{x}}$ & $\mathrm{SD}$ & $\mathrm{h}^{2}$ & $\mathrm{SE}$ \\
\hline Non return rate to 56. day & 0.73 & 0.39 & 0.012 & 0.009 \\
Non return rate to 72. day & 0.69 & 0.42 & 0.010 & 0.009 \\
Age at first service & 537.6 & 75.5 & 0.324 & 0.033 \\
Age of conception & 556.8 & 79.0 & 0.312 & 0.021 \\
Age at calving & 835.8 & 83.2 & 0.296 & 0.019 \\
\hline
\end{tabular}

Relations among ages at first insemination, conception and calving are shown in Table 4. The largest genetic correlation was found between age at first service and age at calving (0.98). The correlation between age at first service and age at conception was slightly smaller (0.96).

TABLE 4

Genetic (above diagonal) and phenotypic (below diagonal) correlations of fertility traits

\begin{tabular}{clccrrr}
\hline No. & Trait & 1 & 2 & 3 & \multicolumn{1}{c}{4} & \multicolumn{1}{c}{5} \\
\hline 1 & Non return rate to 56. day & & 0.80 & 0.10 & 0.05 & -0.11 \\
2 & Non return rate to 72. day & 0.48 & & -0.05 & -0.08 & -0.05 \\
3 & Age at first service & 0.12 & -0.02 & & 0.96 & 0.98 \\
4 & Age at conception & -0.12 & -0.02 & 0.78 & & 0.98 \\
5 & Age at calving & -0.20 & -0.08 & 0.80 & 0.98 & \\
\hline
\end{tabular}

estimated $\mathrm{SE}$ for $\mathrm{r}_{\mathrm{g}}$ ranged from 0.05 to 0.15

The genetic correlation between NR56 and NR72 was high (0.80) whereas the correlations between non-return rates and the remaining traits were low. The highest and negative correlation was found for NR72 and age at conception (-0.11). A positive correlation was obtained for NR56 and age at first service (0.10).

Phenotypic correlations among age at first service, age at conception and age at calving were positive and large. The highest correlation was found between age 
at calving and age at conception (0.98), and the lowest between age at first service and age at conception (0.78). A lower phenotypic correlation was found between NR56 and NR72 (0.48). Correlations between non-return rates and the remaining traits, were low and ranged from -0.20 for NR56 and age at calving to 0.12 for NR56 and age at first service.

\section{DISCUSSION}

The decrease in age at first insemination for cows born in consecutive years, from about 19 months in 1996 to 17 in 2000, reflects the trend in Polish dairy cattle breeding. The average age at calving decreased in the same period from 29 to 27.5 months. Pirlo et al. (2000) showed a positive effect of age at first calving on milk, and a negative effect on protein percentage, concluding that the optimal age at first calving is between 23 and 24 months. Gill and Allaire (1976) found that the optimal age of first calving for total lifetime performance occurs at 23 months, and for maximum profit per day for herd life at about 25 months.

Hibner et al. (1993) showed that the optimal age of first calving for Black-andWhite heifers increased with the percentage of HF genes. In our data the average age of calving for pure Black-and-White cows and cows with $0.1-25 \% \mathrm{HF}$ genes was in general 10 days less than for cows with $25.1-75 \%$ HF genes. However, age at calving of pure Holstein-Frisians was similar to that of pure Black-and-White cows.

One of the most important fertility traits included in total merit indices in many countries is non-return rate. The non-return rate found by Ranberg et al. (2003) in a population of heifers in Norway was $74.6 \%$, very similar to NR56 reported in this paper. The heritability of NR56 in the Norwegian population varied from 0.012 to 0.014 depending on the model applied. Heritability of NR56 estimated by Wall et al. (2003) in a population of British Holsteins was slightly higher (0.018). Heritability for non-return rate to 90th day estimated by Hodel et al. (1995) was lower for heifers (0.011) and higher for cows (0.021). In populations of Israeli Holstein dairy cattle, Weller and Ezra (2003) estimated heritability of the trait defined as the inverse of the number of inseminations to conception for parities from the first through fifth. In general the heritabilities did not exceed 0.02 , and only in the second parity were slightly higher (0.03). All heritabilities reported in the literature were higher than these obtained in our study, which did not exceed 0.01 .

Heritabilites for number of services per conception reported in the literature are higher than for non-return rate. Dematewewa and Berger (1998) estimated heritability of 0.028 for number of inseminations per conception in the Holstein 
population in Iowa. Heritability of 0.039 for the same trait in the population of cattle in the Netherlands was estimated by Veerkamp et al. (2001). Lower heritability (0.020) was found by Wall et al. (2003). Only dates of first and last services were available in our data, so the heritability of number of inseminations per conception could not be estimated.

Heritabilities of age at first service, age at conception and age at first calving estimated in this paper were high and similar to these given by Jagusiak and Żarnecki (2001). Published heritabilities are inconsistent, and range from 0.034 for age at first calving (Moore et al., 1990) and 0.06 for age at first service (Pryce et al., 2001) to 0.22 and 0.43 for age at first service and age at first calving, respectively (Simerl et al., 1991).

As expected, age at first service, age at conception and age at calving were highly correlated. Many cows are inseminated and conceived on the same day, but for other cows the inseminations must be repeated. The interval between insemination and conception depends on many factors, and decreases the phenotypic correlation between age at first service and the remaining traits. Very high (close to 1.0) genetic and phenotypic correlations between age at conception and age at calving were expected because of the very small variance of number of pregnancy days.

In general, genetic and phenotypic correlations between non-return rates and other traits were low. Early inseminated heifers more often repeated heat, which resulted in a positive correlation between non-return rate and age of first insemination. Negative correlations of non-return rates with age of conception and age of calving imply that heifers that did not repeat heat conceived earlier and calved earlier.

Other fertility traits such as service period, days open and calving interval will be analysed in the next paper.

\section{CONCLUSIONS}

Age at first insemination and age at calving decreased in consecutive years and were close to optimal for cows born in 2000. Heifers with intermediate percentages of HF genes were inseminated and calved slightly earlier than pure Black-and-White and pure Holstein-Friesians. Heritabilities of age at first insemination, age at conception and age at calving were within the range of published results. Due to high genetic and phenotypic correlations, only one of these traits should be evaluated and included in cow fertility index. Heritabilities of NR56 and NR72 were low but enough to include non-return rates in the national evaluation system. 


\section{REFERENCES}

Antkowiak I., Pytlewski J., 1997. Estimation of reproduction parameters in cows: Jersey, crossbred Jersey $\times$ Black and White, native Black and White and imported Black and White (in Polish). Rocz. AR Pozn. CCXCIX, Zoot., 49, 3-9

Bagnato A., Oltenacu P.A., 1994. Phenotypic evaluation of fertility traits and their association with milk production of Italian Friesian cattle. J. Dairy Sci. 77, 874-882

Boichard D.E., Barbat A., Briend M., 1997. Genetic evaluation for fertility in French dairy cattle. In: Proceedings of the International Workshop on Genetic Improvement of Functional Traits in Cattle; Fertility and Reproduction. Grub (Germany). Interbull Bull. No. 18, 99-101

Boichard D.E. Manfredi M., 1992. Genetic analysis of fertility in the French Holstein population. Proceedings of 43th EAAP-Congress, Madrit., Vol. I, p. 88

Brzozowski P., 1985. Influence of calving season on some fertility indices of cows (in Polish). Zesz. probl. Post. Nauk rol. No. 300, 269-273

Cermák V., Slapnika J., Přibyl J., Barto L., 1997. Reproduction traits evaluation in cattle in the Czech Republic. In: Proceedings of the International Workshop on Genetic Improvement of Functional Traits in Cattle; Fertility and Reproduction. Grub (Germany), Interbull Bull. No. $18,114-116$

Dematewewa C.M.B., Berger P.J., 1998. Genetic and phenotypic parameters for 305-day yield, fertility, and survival in Holsteins. J. Dairy Sci. 81, 2700-2709

Gianola D., Foulley J.L., 1983. Sire evaluation for ordered categorical data with a threshold model. Genet. Sel. Evol. 15, 201-223

Gill G.S., Allaire F.R., 1976. Relationships of age at first calving, days open, days dry, and herdlife to a profit function for dairy cattle. J. Dairy Sci. 59, 1131-1139

Hansen L.B., Freeman A.E., Berger P.J., 1983. Yield and fertility relationships in dairy cattle. J. Dairy Sci. 66, 293-305

Hansen M., Lund M. S., Pedersen J., Chridtensen L.G., 2004. Genetic Parameters for Stillbirth in Danish Holstein Cows Using Bayesian Threshold Model. J. Dairy Sci. 87, 706-716

Hibner A., Ziemiński R., Sakowski T., 1993. An attempt at determining the optimum time of first calving for polish black-and-white $\times$ holstein friesian crossbred cows $\left(\mathrm{f}_{1}\right)$ (in Polish). Pr. Mat. Zoot. 44, 71-77

Hodel F., Moll J., Kuenzi N., 1995. Analysis of fertility in Swiss Simmental cattle - Genetic and environmental effects on female fertility. Livest. Prod. Sci. 41, 95-103

Hoekstra J., van der Lugt A.W., van der Werf J.H.J., Ouweltjes W., 1994. Genetic and phenotypic parameters for milk production and fertility traits in upgraded dairy cattle. Livest. Prod. Sci. 40, $225-232$

Hyppänen K., Juga J., 1997. Environmental and genetic effects on the 60-day non return rate in Finnish AI bulls. In: Proceedings of the International Workshop on Genetic improvement of Functional Traits in Cattle; Fertility and Reproduction. Grub (Germany). Interbull Bull. No. 18, 91-98

Jagusiak W., Ptak E., 2003. Inbreeding in Polish Black-and-White Cattle. (Inbred w populacji polskiego bydła czarno-białego). Rocz. Nauk. Zoot., Supl. 17, 377-380

Jagusiak W., Żarnecki A., 2001. Genetic parameters of fertility traits in Black-and-White cows (in Polish). XIV Proceedings of Congress Polish Society, p. 207

Jansen J., 1985. Genetic aspect of fertility in dairy cattle based on analysis of AI data a review with emphasis on areas for further research. Livest. Prod. Sci. 12, 1-12

Jong de G., 1997. Index for daughters' fertility in the Netherlands. In: Proceedings of the International Workshop on Genetic Improvement of Functional Traits in Cattle; Fertility and Reproduction. Grub (Germany). Interbull Bull. No. 18, 102-105 
Kamieniecki H., Klimczak K., Stenzel R., 1991. Comparison of the reproductive indices of cows descended from nothwestern and southwestern parts of Poland (in Polish). Zesz. Nauk. AR Szczecin, Zoot. XXV, 148, 55-62

Kuczaj M., 1985. Investigation on reproduction traits of cows in herds at different production levels (in Polish). Zesz. Nauk. AR Wrocław, Zoot. XXVIII, 151, 27-37

Lawson L.G., Bruun J., Coelli T., Agger J.F., Lund M., 2004. Relationships of efficiency to reproductive disorders in Danish milk production: A stochastic frontier analysis. J. Dairy Sci. 87, 212-224

Lucy M.C., 2001. Reproductive loss in high-producing dairy cattle: where will it end? J. Dairy Sci. $84,1277-1293$

Miesenberger J., Sölkner J., Essl A., 1997. Economic weights for fertility and reproduction traits relative to other traits and effects of including functional traits into a total merit index. In: Proceedings of the International Workshop on Genetic Improvement of Functional Traits in Cattle; Fertility and Reproduction. Grub (Germany). Interbull Bull. No. 18, 78-84

Miglior F., Pizzi F., Guaita N., 1997. Effect of environmental factors on non return rate in Italian HolsteinFriesian. In: Proceedings of the International Workshop on Genetic Improvement of Functional Traits in Cattle; Fertility and Reproduction. Grub (Germany). Interbull Bull. No. 18, 106-108

Misztal I., Perez-Enciso M., 1993. Sparse matrix inversion for restricted maximum likelihood estimation of varince componenets by expectation-maximization. J. Dairy Sci. 76, 1479-1483

Moore R.K.B., Kennedy B.W., Schaeffer L.R., Moxley J.E., 1990. Relationships between age and body weight at calving and production in first lactation Ayrshires and Holsteins. J. Dairy Sci. 74, 269-278

Nebel R.L., McGilliard M.L., 1993. Interactions of high milk yield and reproductive prformancein dairy cows. J. Dairy Sci. 77, 3257-3268

Oltenacu P. A., Frick A. Lindhe B., 1991. Relationship of fretility to milk yield in swedish cattle. J. Dairy Sci. 74, 264-268

Pasman E., Reinhardt F., 1997. Genetic evaluation for NR90 of Holstein cattle in Germany. In: Proceedings of the International Workshop on Genetic Improvement of Functional Traits in Cattle; Fertility and Reproduction. Grub (Germany). Interbull, Bull. No. 18, 109-113

Pirlo G., Miglior F., Speroni M., 2000. Effect of age at first calving on production traits and on difference between milk yield returns and rearing costs in Italian Holsteins. J. Dairy Sci. 83, 603-608

Pryce J.E., Coffey M.P., Simm G., 2001.The relationship between body condition score and reproductive performance. J. Dairy Sci. 84, 1508-1515

Pryce J.E., Esslemont R.J., Thompson R., Veerkamp R.F., Kossaibati M.A., Simm G., 1998. Estimation of genetic parameters using health, fertility and production data from a management recording system for dairy cattle. Anim. Sci. 66, 577-584

Ranberg I.M.A., Heringstad B., Klemetsdal G., Svendsen M., Steine T., 2003. Heifer fertility in Norwegian dairy cattle: variance components and genetic change. J. Dairy Sci. 86, 2706-2714

Ranberg I.M.A., Steine T., Klementsdal G., 1997. Breeding for female fertility - current status and future possibilities in Norway. In: Proceedings of the International Workshop on Genetic Improvement of Functional Traits in Cattle; Fertility and Reproduction. Grub (Germany). Interbull Bull. No. $18,87-90$

Roxström A., Strandberg E., Berglund B., Emanuelson U., Philipsson J., 2001. Genetic and environmental correlation among female fertility traits and milk production in different parities of Swedish Red and White dairy cattle. Acta Agr. Scand., Sect. A., Anim. Sci. 51, 7-14

Royal M.D., Flint A.P.F., Woolliams J.A., 2002. Genetic and phenotypic relationships among endocrine and traditional. Fertility traits and production traits in Holstein-Friesian dairy cows. J. Dairy Sci. 85, 958-967 
Simerl N.A., Wilcox C.J., Thatcher W.W. Martin F.G., 1991. Prepartum and peripartum reproductive performance of dairy heifers freshening at young ages. J. Dairy Sci. 74, 1724-1729

Strandberg E., Danell B., 1989. Genetic and phenotypic parameters for production and days open in the first three lactations of Swedish dairy cattle. Acta Agr. Scand. 39, 203-215

Thaller G., 1997. Genetic and breeding for fertility. In: Proceedings of the International Workshop on Genetic Improvement of Functional Traits in Cattle; Fertility and Reproduction. Grub (Germany). Interbull Bull. No. 18, 55-61

Veerkamp R.F., Koenen E.P.C., De Jong G., 2001. Genetic correlations among body condition score, yield, and fertility in first-parity cows estimated by random regression models. J. Dairy Sci. 84, $2327-2335$

Wall E., Brotherstone S., Woolliams J.A., Banos G., Coffey M.P., 2003. Genetic Evaluation of Fertility Using Direct and Correlated Traits. J. Dairy Sci., 86, 4093-4102

Washburn S.P., Silvia W.J., Brown C.H., McDaniel B.T., McAllister A.J., 2002. Trends in reproductive performance in Southeastern Holstein and Jersey DHI herds. J Dairy Sci., 85, 244-251

Weller J.I., Ezra E., 2004. Genetic analysis of the Israeli Holstein dairy cattle population for production and nonproduction traits with a multitrait animal model. J. Dairy Sci. 87, 15191527

Westell R.A., Quaas R.L., Van Vleck L.D., 1988. Genetic groups in animal model. J. Dairy Sci. 71, 1310-1320

Ziemiński R., Hibner A., Juszczak J., 1991. Formation of fertility indices in crossbred cows with different share of HF (in Polish). Rocz. Nauk rol., B - 107 (3), 57-64

\section{STRESZCZENIE}

\section{Cechy płodności w polskiej populacji bydła czarno-białego. 1. Parametry genetyczne cech płodności pierwiastek}

Na podstawie danych dotyczących pierwszych laktacji 42283 krów czarno-białych oszacowano parametry genetyczne następujących cech płodności: wieku pierwszego zabiegu inseminacyjnego, pierwszego zacielenia, oraz ocielenia, a także wskaźników nie powtarzania rui do 56 (NR56) i do 72 dnia (NR72) po pierwszym zabiegu unasienienia. Krowy, u których nie stwierdzono objawów rui do 56 i 73 dnia po zabiegu stanowiły odpowiednio 73 i 69\% badanej populacji. Odziedziczalności NR56 i NR72 wynosiły 0,012 i 0,010. Odziedziczalności wieku pierwszego zabiegu inseminacyjnego, pierwszego zacielenia i pierwszego ocielenia wynosily odpowiednio: 0,324, 0,312 i 0,296. Korelacje fenotypowe wahały się od 0,78 (pomiędzy wiekiem pierwszego zabiegu i wiekiem zacielenia) do 0,98 (pomiędzy wiekiem zacielenia i wiekiem ocielenia). Korelacje genetyczne pomiędzy tymi trzema cechami były wyższe od 0,96 . Korelacje genetyczne między współczynnikami niepowtarzalności rui były bliskie zera. Duże odziedziczalności wysoko skorelowanych: wieku pierwszej inseminacji, pierwszego zacielenia i pierwszego ocielenia oznaczają, że dla jednej z tych cech należy szacować wartość hodowlaną. Odziedziczalności cech niepowtarzalności rui są niskie, ale również wystarczające dla celów szacowania wartości hodowlanych i uwzględnienia ich w programie selekcji. 